\title{
Correction to: Attenuation of glycation and biochemical aberrations in fructose-loaded rats by polyphenol-rich ethyl acetate fraction of Parkia biglobosa (jacq.) Benth. (Mimosaceae) leaves
}

\author{
Christian Chiazor Chibuogwu ${ }^{1,2}$, Rita Onyekachukwu Asomadu ${ }^{1 *}$, Innocent Uzochukwu Okagu 1*, \\ Chinelo C. Nkwocha ${ }^{2}$ and Ben Chibuzo Amadi ${ }^{2}$
}

Correction to: Clinical Phytoscience 7, 41 (2021) https://doi.org/10.1186/s40816-021-00277-1

After publication of the original article [1], the authors identified an error in the author name of Rita Onyekachukwu Asomadu.

The incorrect author name is: Rita Oyekachukwu Asomadu.

The correct author name is: Rita Onyekachukwu Asomadu.

The author group has been updated above and the original article [1] has been corrected.

\begin{abstract}
Author details
'Department of Biochemistry, Medical Biochemistry, Toxicology and Drug Discovery Unit, University of Nigeria, Nsukka, Enugu State, Nigeria. ${ }^{2}$ Institute for Drug-Herbal Medicine-Research and Development, University of Nigeria, Nsukka, Enugu State, Nigeria.
\end{abstract}

Published online: 10 May 2021

\section{Reference}

1. Chibuogwu, et al. Attenuation of glycation and biochemical aberrations in

fructose-loaded rats by polyphenol-rich ethyl acetate fraction of Parkia biglobosa (jacq.) Benth. (Mimosaceae) leaves. Clin Phytosci. 2021;7:41.

https://doi.org/10.1186/s40816-021-00277-1.

The original article can be found online at https://doi.org/10.1186/s40816021-00277-1.

* Correspondence: rita.asomadu@unn.edu.ng; innocent.okagu@unn.edu.ng ${ }^{1}$ Department of Biochemistry, Medical Biochemistry, Toxicology and Drug Discovery Unit, University of Nigeria, Nsukka, Enugu State, Nigeria

\section{Springer Open}

(- The Author(s). 2021 Open Access This article is licensed under a Creative Commons Attribution 4.0 International License, which permits use, sharing, adaptation, distribution and reproduction in any medium or format, as long as you give appropriate credit to the original author(s) and the source, provide a link to the Creative Commons licence, and indicate if changes were made. The images or other third party material in this article are included in the article's Creative Commons licence, unless indicated otherwise in a credit line to the material. If material is not included in the article's Creative Commons licence and your intended use is not permitted by statutory regulation or exceeds the permitted use, you will need to obtain permission directly from the copyright holder. To view a copy of this licence, visit http://creativecommons.org/licenses/by/4.0/. 